\title{
Emergency online learning during the first Covid-19 period: students' perspectives from Bosnia and Herzegovina, North Macedonia, Poland and Turkey
}

\author{
Lina Miloshevska, ${ }^{1}$ Elżbieta Gajek, ${ }^{2}$ \\ Nihada Delibegović Džanić ${ }^{3}$ \& Çiler Hatipoğlu ${ }^{4}$ \\ 1 University of Information Science and Technology "St. Paul the Apostle," \\ Ohrid, North Macedonia \\ 2 Univeristy of Warsaw, Poland \\ ${ }^{3}$ University of Tuzla, Bosnia and Herzegovina \\ ${ }^{4}$ Middle East Technical University, Ankara, Turkey
}

\begin{abstract}
In spring 2020 both teachers and learners experienced the interruption of education as it had been established for over 150 years and seemed to be unchangeable. The paper focuses on students' perspectives on how they perceive the changes in learning due to the pandemic educational emergency response based on the results of a survey of students in four countries: Bosnia and Herzegovina, North Macedonia, Poland and Turkey. We aim at discussing the data collected at the end of the 2019-2020 Spring semester. The research focuses on the accessibility of the tools for learning, modes of instruction, as well as interaction patterns. In addition, we present students' opinions on the difficulties they experienced, the learning strategies they adopted and what aspects of online learning should remain as a regular educational practice after the pandemic period.

Key words: pandemic educational emergency response; students' perspective; Bosnia and Herzegovina; North Macedonia; Poland; Turkey.
\end{abstract}

\section{Introduction: Overview of the call for educational change}

Covid-19 brought a new reality to the world. In trying to cope with the socalled "invisible enemy," countries worldwide implemented different measures that affected many sectors, of which education was one of the most affected. To prevent the spread of the virus, most governments around 
the world temporarily shut down educational institutions at all levels. The consequences of the forced interruption of classes are far-reaching, and this measure directly affected $60 \%$ of the world's population, individuals involved in the educational process. ${ }^{1}$ The transition from in-person to online learning is not at all a simple endeavor. In addition to adequate technical infrastructure and a certain competence in digital skills, the implementation of the learning process requires tremendous support from involved parties: teachers, institutional support, as well as family members. This situation has created exceptional stress not only for teachers, who are pushed into a new unexpected task, but also for students because they had to replace daily school activities and socializing with electronically received assignments. Moreover, many parents found themselves under enormous pressure in trying to help their children as much as possible to adapt more quickly and painlessly to the rapid change.

Not at all easy, e-learning requires tremendous organizational effort, course design and instruction design suitable for the digital medium in order to engage and maintain the attention of students (in some cases digitally more literate than their teachers). As expected, participation and fulfillment of online course requirements is different for students at different educational levels because of the different levels of their learner autonomy. Moreover, the general social blockade made technology in the educational process a condition without which it is not possible to conduct, nor follow any educational activities, as now technology is a must and not a luxury. This brought to the front the digital gap/inequality between developed and less developed countries. In less developed countries the move to digital learning is based usually on the unfounded assumption that all students and teachers have access to broadband internet and proper devices. In fact, access to the Internet and devices is one of the main problems. Therefore, in this crisis, students from less advantaged families are mostly affected. They incomparably lose more from learning during the Covid-19 crisis, compared to their more financially advantaged peers. According to UNICEF, At least a third of the world's schoolchildren - 463 million children globally - were unable to access remote learning during the Covid-19 pandemic. Recognizing that the "digital divide" exists and must be adequately dealt with, many countries in the world put educational programs on national TV services to reach those with poor internet connection.

Crawford et al. (2020), report on the response of 20 universities around the world to the Covid-19 crisis. Their findings show that there was not a unified approach to tackling the global challenge. Organizationally, many things depend on the established infrastructure for conducting e-learning,

\footnotetext{
${ }^{1}$ https://en.unesco.org/covid19/educationresponse/
} 
primarily IT infrastructure, digital skills and digitalization of the educational process. National policies depend on the applied educational models. The response to the crisis is different among those countries that have a centralized education system, compared to those where educational institutions enjoy greater autonomy in design and implementation of teaching.

In an attempt to contribute to the creation of measures informed by data, we prepared this analysis of the ways online learning was conducted in Bosnia and Herzegovina (B\&H), North Macedonia (MK), Poland (PL), and Turkey (TR), the challenges students faced during the online learning period, students' attitudes to different online learning methods, the tools utilized during the online learning period, and the future steps to be considered for improvement of online learning. The main goal is to contribute to the creation of an appropriate approach for the effective implementation of the educational process if it must be implemented digitally and remotely due to this or a similar crisis, but also to the modernization of educational practices to meet the challenges of modern times.

The current study includes the analysis of the following:

1. Analysis of the legal framework of Bosnia and Herzegovina, North Macedonia, Poland and Turkey for introducing and conducting online learning during the emergency of the Covid-19 pandemic.

2. Findings obtained on the basis of a survey of students involved in the educational process in Bosnia and Herzegovina, North Macedonia, Poland and Turkey in relation to their attitudes and opinions to online learning and comparative analysis of the findings of the four countries included in the study.

3. Suggestions for improvement of online learning, both country specific, and cross cultural.

\section{The change of unchangeable components of the learning and teaching environment}

Calls for change in education have a long history. Visionaries dreamt of learning societies (Faure et al., 1973), and lifelong learning (Delors et al., 1996), although the first attempts have been criticized for utopian vision of education (Elfert, 2019). In the period from 1979 to 2019 many scholars e.g. A report of the Club of Rome (Botkin et al. 1979) and White Paper on "Teaching and Learning: Towards the Learning Society" (Cresson \& Flynn, 1995) expressed the need for a change including the need to respond to challenges introduced by information technologies. In recent years also OECD has put emphasis on the teaching profession contributing to the spread of understanding of the nature of envisaged change (PISA, 2018; Guerriero, 2017; 
teachers' guide to TALIS, 2018; Paniagua \& Istance, 2018). However, it has been hard to put the general ideas into practice in the era of fast changes in digital technologies.

\subsection{Place and means of learning and teaching}

The foundations of the contemporary educational system were set in the $17^{\text {th }}$ century by Comenius (1657) with the division of children assigned to classes according to their age and consequent expected promotion to higher levels. The system was refined in the mid-19th century and has stayed almost unchanged since then. Such education requires infrastructure - buildings with specialized equipment that is provided by local authorities or private entities.

Young people attended schools separated from their families for a shorter or longer period of time to be taught by one or more professionals. Parents were not present in the educational context (schools), and teachers taught in real time and in the real world. Students were given resources to support their literacy/educational needs. In contrast, distance education or online education in our context has emerged in response to the need to continue the educational process, while reducing the spread of Covid-19. It was necessary for the students to stay at home. Parents are present in the context of education and have taken on different organizational roles that are usually performed by teachers and schools. Teachers provide materials that students can access synchronously/asynchronously. Students may or may not have access to the resources needed to participate in and support their learning.

After the change brought by the outbreak of Covid-19, learners required immediate access to high quality digital devices and a broadband connection to the internet to be able to participate in online lessons. In the present study, the term online learning refers to "a type of teaching and learning situation in which (1) the learner is at a distance from the tutor/instructor, (2) the learner uses some form of technology to access the learning materials, (3) the learner uses technology to interact with the tutor/instructor and with other learners and (4) some kind of support is provided to learners" (Anderson 2011a, as cited in Rapanta et al., 2020).

\subsection{Modes of instruction and communication patterns}

In traditional educational settings, the main mode of instruction has been built on interactions between the teacher and the learners and among the learners themselves including verbal and nonverbal means. In addition, there are plenty of opportunities for accidental or intentional interactions among learners during breaks and before and after classes. Learners also 
interact with the supporting staff in the institutions. Learners did not need specialized equipment for such interactions to happen. On the other hand, online instruction offers certain forms of interaction between teacherstudent, peer to peer or group work but certainly in a virtual environment that does not offer the complex and rich subtle clues available in face-to-face interaction. Also the level of formality or informality of teacher-students' interactions may be perceived differently in face-to face and online learning environments. For example, the teacher walking in the class monitoring individual or group work is able to notice and respond to the students' needs faster and better than in an online classroom. In online classes students are deprived of incidental interactions among themselves and with other members of the staff.

\subsection{Learning competences}

Before Covid-19 pandemic, computer literacy among learners was optional. Learners gained their basic digital literacy mainly through specialized courses integrated in the curriculum at the elementary and secondary educational levels. Strategies for using learning technology have been discussed among specialists since the 1980's (Chapelle \& Jamieson, 1986, 1989; Chapelle, 1990, 1995) with a particular emphasis on metacognitive strategies (Hauck, 2005; Hauck \& Hurd, 2005). Healey et al, (2011:19-70) in their TESOL Standards set clearly the goals and standards for learners defining performance indicators for each standard:

Goal 1: Language learners demonstrate foundational knowledge and skills in technology for a multilingual world.

STANDARD 1: Language learners demonstrate basic operational skills in using various technology tools and internet browsers.

STANDARD 2: Language learners are able to use available input and output devices (e.g., keyboard, mouse, printer, headset, microphone, media player, electronic whiteboard).

STANDARD 3: Language learners exercise appropriate caution when using online sources and when engaging in electronic communication.

Goal 2: Language learners use technology in socially and culturally appropriate, legal, and ethical ways.

STANDARD 1: Language learners understand that communication conventions differ across cultures, communities, and contexts.

STANDARD 2: language learners demonstrate respect for others in their use of private and public information. 
Goal 3. Language learners effectively use and critically evaluate technologybased tools as aids in the development of their language learning competence as part of formal instruction and for further learning.

STANDARD 1: Language learners effectively use and evaluate available technology-based productivity tools.

STANDARD 2: Language learners appropriately use and evaluate available technology-based language skill-building tools.

STANDARD 3: Language learners appropriately use and evaluate available technology-based tools for communication and collaboration.

STANDARD 4: Language learners use and evaluate available technology-based research tools appropriately.

STANDARD 5: Language learners recognize the value of technology to support autonomy, lifelong learning, creativity, metacognition, collaboration, personal pursuits, and productivity.

The standards refer to a variety of learner competences. However, computer-assisted learning remained marginal for years and was perceived as a domain explored by pioneers. Just overnight the ability to learn with the computer as the only means of communication became the most essential competence allowing access to classes and resources. To conclude, the foundations of the learning and teaching educational environment, which lasted for centuries, were broken nearly overnight in March 2020 in many countries around the world.

\section{Online learning before the pandemic in Bosna \& Herze- govina, North Macedonia, Poland, Turkey}

Prior to the outbreak of the pandemic, distance learning was not widely present at universities in Bosnia and Herzegovina, although laws on higher education recognize this type of teaching. The Faculty of Information Technology, Džemal Bijedić University in Mostar is the institution that first introduced a distance learning system in Bosnia and Herzegovina almost twenty years ago. This institution implements its academic programs using both in-class teaching and the distance learning system. The distance learning system developed at this faculty can be applied to other faculties and educational institutions. It is important to highlight that from the very beginning their system has also included video conferences to create proper synchronous lectures and seminars (Memić Fišić \& Delibegović Džanić, 2020). At the University of Tuzla, where this research was conducted, before the outbreak of the pandemic, only one study program was organized as a 
distance learning study program with synchronous teaching tools, while in other programs this system was used as complementary to in-class teaching for individual courses or guest lectures.

In North Macedonia, the Ministry of Education and Science has acknowledged the importance of the use of ICT tools at all levels of education. This is reflected in a number of governmental attempts to modernize and digitalize education. One of the latest documents in that regard is the strategy for education 2018-2025 and action plan². Moodle (http://moodle.org/) is an open source software that operates on different platforms and supports distance learning. Almost all higher education institutions in North Macedonia, both state and private, have been using Moodle for more than ten years. However, Moodle has been used as a support to in-class courses not as separate distance learning courses. To the best of our knowledge no courses have been offered as completely distance learning courses at higher education institutions in North Macedonia before the Covid-19 pandemic.

Before the pandemic almost all universities in Poland used Learning Management Systems mainly as complementary to in-class teaching. The University of Warsaw uses Moodle as its LMS, and they have been developing it for 15 years now. Regular Moodle training was organized for academic teachers. However, it is the teachers' choice as to what extent they will utilize it. The staff has been encouraged for years to extend the offer of courses that can be attended online. Selected courses were taught asynchronously. Language courses were also offered as preparatory courses for the university language exams. The use of LMS's in schools is not common.

Distance education before the pandemic had a long history in Turkey. The idea was first introduced in 1927 when solutions were sought for the low rate of literacy among the population (Alkan, 1987: 91). However, the first application had to wait until the 1950s, when the Ministry of National Education (MONE) established the Centre for Educative Films, where educational films were produced and distributed around the county (Geray, 2007). The first example of distance education at the university level was the education by letters initiated by the Institute of Banking and Commerce in the Faculty of Law at Ankara University, with which bank personnel were trained with letters (Karayalçın, 1959). This system continued to grow, and in 1970 MONE first started open High School educational programs and in 1975 higher education programs by correspondence.

The efforts to widen distance education in Turkey intensified after 1980, when a new constitution was introduced, and a new authority - the Higher Education Council (HEC) - responsible for regulating all higher education in Turkey was founded (Hatipoğlu, 2017). At that time, in 1981, there were 27

${ }^{2}$ http:/ / mrk.mk/wp-content/uploads/2018/10/Strategija-za-obrazovanie-MAK-WEB.pdf 
universities in Turkey, and they were able to accommodate only $5.9 \%$ of applicants (Şimşek, 1999). To educate a bigger number of students for a lower cost, a law was passed, allowing universities to open distance education programs. The first university to take the initiative was Anadolu University (AU), where the distance learning Management and Economics programs were opened in 1982 (https://www.anadolu.edu.tr/en/about-anadolu/ institutional/anadolu-at-a-glance). These programs became really successful, and at the moment, AU has three faculties with over 2 million students where all of the education is done online. Within those faculties, there are 19 undergraduate and 41 associate degree programs that provide distance education to "Turks in the Turkish Republic of Northern Cyprus, Azerbaijan, Kosovo, North Macedonia, Bulgaria, Albania, Bosnia and Herzegovina, Serbia, Moldova, Romania, Montenegro, Western Thrace, North America, Canada, Middle East, Iran and several Western European Countries" (https://www.anadolu.edu.tr/en/open-education/openeducationsystem/ about).

To share the load of AU, in 2009, Istanbul University and Atatürk University also established distance education centers. Istanbul University started with distance education and continued with fully-fledged programs of open education in the Open and Distance Education Faculty (AUZEF) (https://auzef.istanbul.edu.tr/tr/content/fakultemiz/hakkinda). At the moment, AUZEF has 24 undergraduates, 20 associate degrees and 7 undergraduate completion programs. Similarly, Atatürk University started its Distance Education Application and Research Centre (https://atauzem. atauni.edu.tr/s/atauzem-hakkinda) with a single program, but at the moment, it offers 4 undergraduate completion programs and 7 masters degree programs without thesis. Middle East Technical University, where the data were collected, is another Turkish university that provides web-based distance education to students around the country via its Distance Education Centre. At the university, various courses (e.g., Introduction to Information Technologies and Applications, http://ii.metu.edu.tr/is100; Occupational Health and Safety I \& II, http://ohs.metu.edu.tr/ohs101; Principles of Kemal Atatürk I \& II) were already taught online before the pandemic. For all other courses that were not taught online, in the last 15 years, lecturers were using METU CLASS, an LMS system developed by METU. Lecturers were required to upload course outlines and all other course materials on the platform so that all students taking the course had access. 


\section{Policy documents introducing and justifying the emergen- cy online learning in the four countries}

\subsection{Bosnia and Herzegovina}

In order to elaborate on different measures imposed by the governmental authorities in Bosnia and Herzegovina, it is necessary to briefly present the complex political system of the country. Bosnia and Herzegovina consists of two entities and one district: Federation of Bosnia and Herzegovina, Republic of Srpska and Brčko District. The Federation is further divided into ten cantons. Educational policies are not created at the national level, but at the level of entities, cantons and the district. There are twelve ministries of education that create educational policies. Our research was conducted in Tuzla Canton, which is part of Federation of Bosnia and Herzegovina. ${ }^{3}$ The Canton's ministries of health and education were responsible for all decisions and instructions brought during the Covid-19 outbreak.

On 11 March 2020, the Government of Tuzla Canton together with the Government of Federation of Bosnia and Herzegovina adopted a resolution to suspend in-person teaching at the premises of all educational institutions in the canton for a period of two weeks. ${ }^{4}$ All educational institutions had to reorganize their classes almost overnight and start with a variety of online teaching practices. It was soon clear that the pandemic will not be controlled in such a short period of time and hence these measures were prolonged until the end of the school year in June. All lectures and seminars at higher education institutions were delivered online from March till June with the use of Zoom, Google classroom or the internal university learning management system based on Moodle. However, students returned to some universities in June and July to take their exams. The Government let the universities decide whether exams will be organized online or at their premises. The Senate of Tuzla University decided for the second option and their students returned to the university in the summer of 2020.5

The transition to the new reality was challenging both for students and teachers as they had to organize exams in accordance with all restrictions to limit the spread of Covid-19 and the requirements of syllabus of every subject, which was very demanding for everyone especially for the practical parts of exams. The 2020/2021 academic year started with a two-week-

3 Magill, C. (2010). Education and Fragility in Bosnia and Herzegovina. UNESCO and International Institute for Educational Planning. Retrieved from

http://unesdoc.unesco.org/images/0019/001910/191060e.pdf

4 https://covid19.fmoh.gov.ba/novost/62/naredbe-kriznog-stozera-staba-federalnog-ministarstva-zdravstva.

5 http://www.untz.ba/uploads/file/akti/2019-20/Odluka_o_organizaciji_i_realizaciji_nastave_26_05_2020.pdf 
delay. The Senate of Tuzla University opted for the hybrid model of teaching where classes can be organized online using Moodle, Zoom or Google Meet or at the university premises depending on the requirements of study programs. Asynchronous teaching was explicitly marked as unacceptable. ${ }^{6}$

\subsection{North Macedonia}

The education system in North Macedonia is highly centralized although higher education institutions enjoy a certain level of autonomy. Education in the Republic of North Macedonia is regulated by three fundamental laws: Law on Primary Education, Law on Secondary Education and Law on Higher Education. ${ }^{7}$ This legal framework does not provide legislation on distance learning and does not recognize it as a valid model of education. The Covid19 pandemic brought a new reality, so this legal gap has been addressed by decrees with the force of law which were adopted in the time of the state of emergency by the government of North Macedonia.

The intent of the governmental decrees was to provide a legislative framework for online learning/teaching in an attempt to respond to the crisis. Three of the government decrees were aimed at primary education, three at secondary education and four aimed at higher education. These decrees mainly cover technical/administrative aspects, and very few sections deal with the arrangement and realization of the educational process. Additionally, at the time, there were no available guidelines for organizing distance learning and assessment. The only document regarding this issue is the Protocol of instructions for conducting exams at public and private higher education institutions. The Protocol provides guidelines for taking exams at the premises of higher education institutions (public and private) ensuring protection from Covid-19. 8

On 10 March 2020, the Government of the Republic of North Macedonia adopted a resolution to pause in-person teaching at the premises of educational institutions in the country, including higher education institutions, for

6 http:/www.untz.ba/uploads/file/akti/202021/Odluka_o_nacinu_organizacije_nastave_ispita_i_odbrana_zavrsnih_radova_na_UnTz_29_10_2020.pdf.

${ }^{7}$ Law on primary education (Official Gazette No.161/2019), available at: http:/ /www.mon.gov. mk/images/Zakon_za_osnovnoto_obrazovanie_br._161-_2019.pdf; law on secondary education (Official Gazette No. 44/1995, 24/1996, 34/1996, 35/1997, 82/1999,29/2002, 40/2003, 42/2003, 67/2004, 55/2005, 113/2005, 35/2006, 30/2007, 49/2007, 81/2008, 92/2008,33/2010, 116/2010, 156/2010, 18/2011, 42/2011, 51/2011, 6/2012, 100/2012, 24/2013, 41/2014,116/2014, 135/2014, 10/2015, 98/2015, 145/2015, 30/2016, 127/2016, 67/2017 и 64/108) available at: http:/ /mon. gov. mk / stored/document/zakon-za-sredno-obrazovanieprecisten.pdf; Law on higher education (Official Gazette No. 82/2018), available at: http://www. mon.gov.mk/images/ documents/zakoni/ZAKON_VISOKOTO_OBRAZOVANIE-final.pdf.

8 http://www.mon.gov.mk/images/documents/protokoli/Protokol_visoko.pdf. 
a period of 14 days in order to slow down the spread of Covid-19 virus. ${ }^{9}$ The suspension of in-person teaching continued, given the declared state of emergency on 18 March 2020 and the prolonged pandemic. The new situation seriously affected the educational process in North Macedonia and introduced unexpected challenges in every segment of the educational process.

Starting from 11 March 2020, all universities in the country complied with the decision of the Government of North Macedonia to suspend inperson educational activities and informed students of the government's decision. As of 16 March, 2020, the implementation of the education process gradually transitioned to the online space through synchronous and asynchronous communication tools and platforms such as: email, Zoom, Microsoft Teams, Google Classroom, Moodle, Viber, Skype, telephone calls, WEBEX and Courses.

Subsequently, on 23 March 2020, the Government of North Macedonia adopted a Decree with legal force ${ }^{10}$ according to which courses in higher education institutions during the state of emergency should be implemented using electronic communication which provide bi-directional communication, without the physical presence of the participants in the activity. The decree states that higher education institutions themselves can decide what kind of electronic communication they will use. For illustration, the following types of tools were listed: video conferencing platforms, electronic mail and other electronic data exchange systems. ${ }^{11}$

On 23 March, 2020, by decree with legal force, the government of North Macedonia decided that exams and tests be conducted using electronic communication, provided that appropriate technical solutions are secured to ensure the identification and control of student work during exams. Subjects of assessment might be various course related activities such as: tutorials, practical work, field work, seminars, assignments, projects, courses, essays, artistic performances, artistic production, and other activities as per the course requirements. A number of higher education institutions decided to postpone exams and other forms of assessment until safe conditions for inperson realization are available while others implemented online testing and evaluation. As the pandemic continued, a number of institutions conducted

\footnotetext{
${ }^{9}$ Government of North Macedonia (10.3.2020). The educational process in kindergartens, primary, secondary and higher education institutions is stopped. Mass public events and organized trips to high-risk countries are forbidden. Web announcement on the official website of the Government of North Macedonia.

${ }^{10}$ Government of RNM. (23.3.2020). Decree with legal force for application of the Law on Higher Education for during the state of emergency.

${ }^{11}$ Ibid.
} 
their exams in-person during the June-July exam session abiding by Covid19 prevention protocols.

\subsection{Poland}

In Poland, the Ministry of Education regulates the rules for kindergartens, primary and secondary education. All educational institutions at the three levels were closed on 12 March 2020 for two weeks. Then the pandemic lockdown was prolonged several times. Within a few weeks the schools needed to organize online teaching for pupils. The schools were opened temporarily in mid-September 2020 and closed again on the 7 November 2020.12

On the 10th March 2020 the Rector of University of Warsaw closed all courses and recommended the start of full online learning as of 23 March. ${ }^{13}$ This decision was followed by Rectors of other universities in the country as well as recommendations of the Ministry of Science and Higher Education. Then the lockdown was prolonged. The University Library was also closed as well, and all conferences cancelled. The academic staff was not allowed to travel abroad for professional purposes. The university's written language exam - to obtain B2, C1, C2 exams were organized in June 2020 without any change but the oral language exam to fulfil the program requirements was organized online. As of 7 September 2020, all diploma examinations were to be organized online. ${ }^{14}$

The 2020/2021 academic year started with a two-week delay, with all courses which do not require specialized equipment for teaching being taught online. All classes, examinations, and consultations with students had to be performed with the use of Google Meet, Zoom or via the internal university Moodle learning management. Asynchronous teaching only was not approved. As Polish universities enjoy autonomy, the specific safety regulations differ to some extent in different institutions, e.g. in terms of tools such as G-suite or Steams. On 17 December 2020 the two ministries, the Ministry of Education and the Ministry of Science and Higher Education, merged into one: the Ministry of Education and Science. In February 2021 the Ministry decided that all higher education institutions should work online until September 30th 2021. Decisions regarding primary and secondary education schemes were announced in due time.

${ }_{12}$ Dz. U. poz. 410, 492, 595 642, 742, 780, 871, 953, 990, 1004 i 1110.

${ }^{13}$ M.2020.123.Zarz.50.

${ }^{14}$ M.2020.387.Obw.24. 


\subsection{Turkey}

The educational system in Turkey is highly centralized. Before 1981, education at all levels was regulated by the Ministry of National Education (MONE), but in 1981 (with Act No: 2574) a major reform was implemented. With it, the "responsibility for training teachers was transferred from the MONE to universities through the Higher Education Council (Yüksek Öğretim Kurumu, HEC)" (Hatipoğlu, 2017: 240). The Faculties of Education, where the Turkish corpus was collected, offer four-year-long programs that are prepared and regulated by HEC. All decisions related to the type of education are also taken by HEC (Hatipoğlu, 2010; 2016). Before the pandemic, most of the instruction at the Faculties of Education (apart from Anadolu University Faculty of Open Education, Istanbul University, Atatürk University) in Turkey was done face-to-face, with the bulk of courses such as School Experience and Practice Teaching completed in practicum schools. ${ }^{15}$

The classes of the spring 2019-2020 semester started on February 03, 2020 and many of the classes were face-to-face. The first COVID-19 case in Turkey was reported on March 11, $2020^{16}$ (i.e., in week 6 of the 14-week long semester), but before that, on March 06, 2020, $\mathrm{HEC}^{17}$ had released a statement with which it notified all universities in Turkey that face-to-face education was going to be suspended till March 22, 2020 because of the widespread COVID-19 cases around the world in general, and in Turkey's neighboring countries, in particular. The published circular letter was ordering universities with suitable infrastructure and platforms to move from face-to-face to online teaching in two weeks (i.e., from March 23, 2020 onwards). HEC, with the help of all universities in Turkey, created an open course material pool for university students lacking the required infrastructure and platforms. These included videos, PowerPoint presentations, course notes, and various handouts.

On March 16, 2020, the president of Middle East Technical University (METU) sent an email informing lecturers and students that face-to-face education at METU had been suspended, the library and the sports' facilities on campus had been closed, all conferences had been cancelled, and following the circular letter from the Turkish Presidency on March 12, 2020,18 all travel abroad for either professional or personal reasons was banned. So, both lecturers and students who had started and completed the first six

\footnotetext{
${ }^{15} \mathrm{http}$ // / fle.metu.edu.tr/en/foreign-language-education-undergraduate-programs ${ }^{16} \mathrm{https}$ // / www.trthaber.com/haber/gundem/turkiyede-ilk-koronavirus-vakasi-tespit-edildi466216.html

${ }^{17}$ https:/ / basin.yok.gov.tr/ AciklamaBelgeleri/2020/03-uzaktan-egitime-iliskin-alinankarar.pdf

${ }^{18}$ https://www.resmigazete.gov.tr/eskiler/2020/03/20200313.pdf
} 
weeks of the Spring 2019-2020 term face-to-face had to reorganize everything and move to $100 \%$ online teaching and learning. The university lecturers were given a choice between asynchronous and synchronous teaching, and the majority of them selected asynchronous instruction, with a few opting for either synchronous or hybrid teaching. The teaching staff were informed that for their online classes they could use ZOOM, WebEx, or METU CLASS. The last of those options is a learner management system which was developed by METU, and staff and students had been using it for the last 15 years. METU CLASS is a platform where the lecturers can create, open and/or upload activities (e.g., assignments, forums, questionnaires) and materials (e.g., their course outlines, course reading materials, handouts, PowerPoint presentations) (https://odtuclass.metu.edu.tr/). The platform is also open to students, and they are able to upload their project work, participate in the forums and focus groups, see their exam results etc. All materials uploaded to METU CLASS can be reached and downloaded by every student taking the course.

On March 26, 2020,19 HEC issued another circular letter informing universities about the decision that the Spring 2019-2020 term would be completed online. Following this announcement, on March 30, 2020, METU Presidency informed METU staff and students that the Spring 2019-2020 semester had been extended for four weeks: "based on the feedback that the distance education decision was taken a week after the decision to take a break was made and that the instructors spent the first week of the distance education period, started on 23 March, adapting their courses to the new system, and that this week should be considered as a period of implementing these adaptations to the system, we are intending to extend the end of term from 08 May 2020 up until 05 June 2020 depending on the instructors' needs." The decision not to return to face-to-face education added an extra challenge of not only teaching but also assessing students online, which was not something that was done frequently at METU.

In conclusion, it is worth mentioning that the measures taken by different educational institutions in the four countries are similar in terms of their timeline in response to the pandemic and in terms of the solutions offered to continue the academic year regardless of the centralized versus decentralized systems in place and their previous experiences with distance learning as discussed in section 3 above. These measures in Bosnia and Herzegovina, North Macedonia, Poland, and Turkey are in line with the actions taken by universities in 20 countries discussed by Crawford et al. 2020, which varied from no response to in-campus isolation or fully online teaching.

\footnotetext{
${ }^{19}$ https:/ / basin.yok.gov.tr/ AciklamaBelgeleri/2020/04-uzaktan-egitim-ve-yks-ertelenmesineiliskin.pdf
} 


\section{The study}

\subsection{Aims}

The study aims at capturing students' attitudes and opinions in relation to their experience with online learning during the Covid-19 pandemic. A written survey especially designed for this study was distributed to university students in Bosnia and Herzegovina, North Macedonia, Poland, and Turkey. The survey was distributed in English to a total of 216 students.

The specific research questions that this study aims to answer are:

RQ1: To what extent students in the four countries were prepared for the change in the learning environment in terms of access to digital devices and access to the internet?

RQ2: What are the challenges that students faced during the emergency online learning period?

RQ3 What are the students' opinions on online learning?

RQ4. What processes might or should remain after the pandemic is over?

\subsection{Participants}

Participants in the survey are a total of 216 students studying at higher education institutions in Bosnia and Herzegovina, North Macedonia, and Turkey. Polish participants are high school students, in their pre-university stage. All respondents participated in online classes during the Covid-19 crisis during the period of March to June 2020. The age range of participants is 17-22. Most participants from Turkey $48(64 \%)$ and Bosnia and Herzegovina $52(75.4 \%)$ are female while in North Macedonia mostly are male 31 (63.3\%). The Polish respondents are almost evenly divided between the two genders: 12 males (52.5\%), 10 females (43.5\%). The majority of participants in all four countries $\mathrm{N}=118(54.6 \%)$ evaluated their digital literacy as advanced. Based on this self-evaluation we might assume that participants did not have much difficulty using online learning tools introduced during the emergency online learning Covid-19 period. However, to ensure that our assumption is correct we asked students to identify the difficulties they faced during the online learning period. The findings are discussed in section 6 below.

\subsection{Data collection}

The data analyzed in this study were collected through an online survey especially designed for the purpose of the study. The survey was distributed in English to participants in all four countries covered by the study. All re- 
spondents took online classes and assessment during the emergency Coronavirus online learning. The survey questions are divided into sections that cover the main research questions that motivated this study. ${ }^{20}$

Section 1: Collects background data related to the age, gender, educational level of participants, and computer literacy.

Section 2 is focused on students' usage of online learning tools before and during the Covid-19 crisis, the availability of necessary prerequisites for online learning i.e. internet access, and access to devices, modes of interaction, modes of instruction, as well as challenges faced during the Covid-19 online learning period.

Section 3 tackles students' attitudes towards online learning from different angles. After going through online learning for a while (March-June 2020), respondents are asked to provide their views concerning different aspects of online learning in terms of its efficiency, practicality, advantages and disadvantages.

Section 4 analyzing the effects of online learning on students in terms of whether online learning changed the way students learn and what aspects of online learning should remain and be part of the educational offer after the pandemic is over.

\subsection{Data Analysis}

As the number of participants from each country is not equal and varies from 75 in Turkey, 69 in Bosnia and Herzegovina, 49 in Macedonia, and 23 in Poland, descriptive statistics is used to compare the data. The analysis is based on quantitative data obtained through close questions of the data collection tool. The data collection tool also contained questions related to assessment practices during the emergency online learning period and the role of the teacher. Since assessment and teacher's role deserve to be elaborated on in a separate paper, and for the sake of brevity, the results discussed here will cover data relevant to the current study.

\section{Results and discussion}

Section 2 of the survey aimed to obtain data regarding the usage of online learning tools before and during the Covid-19 crisis, the availability of necessary infrastructure for online learning i.e. internet access, and access to devices, as well as the different forms of interaction during the online learn-

\footnotetext{
${ }^{20}$ Participants were also asked about online assessment and the role of teachers, but these topics are not discussed in this article.
} 
ing and modes of instruction. Table 1 shows that the majority of participants in all four countries have not taken any online courses before the Coronavirus pandemic: $\mathrm{N}=156(72.2 \%)$. One-third of students $\mathrm{N}=74(34.3 \%)$ indicated that they used online learning tools 1-2 times a week before the coronavirus pandemic. However, $\mathrm{N}=68(31.5 \%)$ of participants stated that they never used any online learning tools in their learning. Although these numbers might be surprising yet they correspond with the findings from Hatipoğlu, Gajek, Miloshevska, Delibegović Džanić, (2020) that showed that students rarely utilize online learning tools except for the most common tools such as search engines, Wikipedia and online dictionaries in their studies, unless these tools are specifically recommended and integrated in the course requirements by teachers.

Table 1: Frequency of using online tools before the Covid-19 pandemic

\begin{tabular}{|c|c|c|c|c|c|c|c|c|c|c|}
\hline \multirow{3}{*}{\multicolumn{3}{|c|}{\begin{tabular}{|c|c|}
\multicolumn{2}{|c|}{ Frequency of us } \\
$\begin{array}{c}\text { Bosnia \& } \\
\text { Herzego- } \\
\text { vina }\end{array}$ \\
$\mathrm{N}$ & $0 \%$
\end{tabular}}} & \multirow{2}{*}{\multicolumn{2}{|c|}{$\begin{array}{c}\text { North } \\
\text { Macedonia }\end{array}$}} & \multirow{2}{*}{\multicolumn{2}{|c|}{ Poland }} & \multirow{2}{*}{\multicolumn{2}{|c|}{ Covid-19 pan }} & \multirow{2}{*}{\multicolumn{2}{|c|}{ All }} \\
\hline & & & & & & & & & & \\
\hline & & & $\mathbf{N}$ & $\%$ & $\mathbf{N}$ & $\%$ & $\mathbf{N}$ & $\%$ & $\mathbf{N}$ & $\%$ \\
\hline $\begin{array}{l}\text { Every } \\
\text { day }\end{array}$ & 9 & $13.0 \%$ & 7 & $14.3 \%$ & 1 & $4.3 \%$ & 4 & $5.30 \%$ & 21 & $9.7 \%$ \\
\hline $\begin{array}{l}3-4 \\
\text { times a } \\
\text { week }\end{array}$ & 0 & $0.0 \%$ & 0 & $0.0 \%$ & 0 & $0.0 \%$ & 1 & $1.30 \%$ & 1 & $0.5 \%$ \\
\hline $\begin{array}{l}1-2 \\
\text { times a } \\
\text { week }\end{array}$ & 19 & $23.5 \%$ & 19 & $38.8 \%$ & 8 & $13.0 \%$ & 28 & $37.40 \%$ & 74 & $34.3 \%$ \\
\hline $\begin{array}{l}1-2 \\
\text { times a } \\
\text { month }\end{array}$ & 16 & $23.2 \%$ & 7 & $14.3 \%$ & 3 & $13.0 \%$ & 21 & $28 \%$ & 47 & $21.8 \%$ \\
\hline $\begin{array}{l}\text { couple } \\
\text { of times }\end{array}$ & 0 & $0.0 \%$ & 1 & $2.0 \%$ & 0 & $0.0 \%$ & 0 & $0 \%$ & 1 & $0.5 \%$ \\
\hline Rarely & 0 & $0.0 \%$ & 1 & $2.0 \%$ & 1 & $4.3 \%$ & 0 & $0 \%$ & 2 & $0.9 \%$ \\
\hline $\begin{array}{l}\text { Just one } \\
\text { time for } \\
2 \text { weeks }\end{array}$ & 0 & $0.0 \%$ & 0 & $0.0 \%$ & 0 & $0.0 \%$ & 1 & $1.30 \%$ & 1 & $0.5 \%$ \\
\hline $\begin{array}{l}\text { Just one } \\
\text { time }\end{array}$ & 0 & $0.0 \%$ & 0 & $0.0 \%$ & 0 & $0.0 \%$ & 1 & $1.30 \%$ & 1 & $0.5 \%$ \\
\hline Never & 25 & $34.2 \%$ & 14 & $28.6 \%$ & 10 & $43.5 \%$ & 19 & $25.30 \%$ & 68 & $31.5 \%$ \\
\hline
\end{tabular}


During the online learning period, educational institutions utilized a variety of methods to deliver instruction and learning materials to students. Although many tools such as email, and learning management systems had been widely used before the pandemic in all four countries included in the study, the main novelty was to deliver lectures and tutorials to students using videoconferencing tools to compensate for face to face instruction. This mode of instruction was never used before the pandemic in the four countries at the institutions where the data was collected.

Regarding the modes of instruction utilized at the different educational institutions in the four countries of the study during the emergency online learning period, both synchronous and asynchronous tools were utilized with a certain skew towards one or the other as displayed in Figure 1.

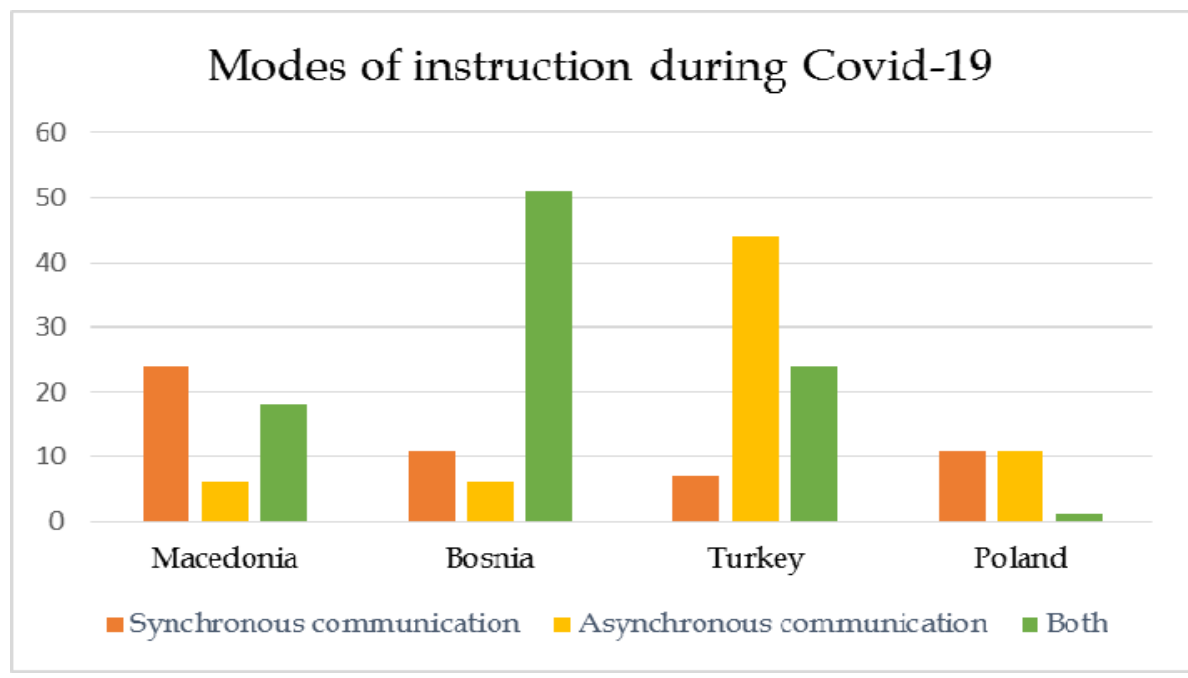

Figure 1: Modes of instruction during Covid-19 period

Figure 1 shows that in North Macedonia, synchronous instruction i.e. online conferencing tools to deliver instruction, was more commonly used which is in compliance with the directives from the Ministry of education stated in section 4.1 above. In Bosnia and Herzegovina and Poland both synchronous and asynchronous instruction were used evenly, whereas in Turkey, the educational institution utilized mostly asynchronous tools such as the university learning management system for instruction during the Covid-19 pandemic since teaching staff in Turkey had been able to choose between synchronous and asynchronous instruction as discussed in section 4.4 above. 
As educational institutions worldwide had to react quickly in order to offer an alternative for in-person teaching using the available digital resources to ensure the continuity of the educational process, little or no time was available to check whether students had access to the necessary technology to participate in online learning. As online instruction en masse started, it was quickly accompanied by digital inequality concerns (Jena, 2020; Reimers \& Schleicher, 2020; Bonal \& Gonzalez, 2020). The public and academic debates at the time highlighted complaints and concerns regarding the efficiency of online learning given the circumstances were many financially less advantaged students lacked the necessary prerequisites to participate in online instruction.

In the present study we asked participants to rate their access to the internet and the necessary devices to follow online instruction. Table 2 shows that the majority of respondents in all four countries stated that they had excellent or very good access to devices $\mathrm{N}=172(79.6 \%)$. Moreover, most participants stated that they had excellent or very good access to the internet $\mathrm{N}=139(64.4 \%)$. Table 3 displays the data.

Table 2: Access to devices

\begin{tabular}{|c|c|c|c|c|c|c|c|c|c|c|}
\hline \multicolumn{11}{|c|}{ Access to devices } \\
\hline & \multicolumn{2}{|c|}{$\begin{array}{c}\text { BOSNIA } \\
\text { AND } \\
\text { HERZEGOVI } \\
\text { NA }\end{array}$} & \multicolumn{2}{|c|}{$\begin{array}{c}\text { NORTH } \\
\text { MACEDON } \\
\text { IA }\end{array}$} & \multicolumn{2}{|c|}{ POLAND } & \multicolumn{2}{|c|}{ TURKEY } & \multicolumn{2}{|c|}{ All } \\
\hline & $\mathrm{n}$ & $\%$ & $\mathrm{n}$ & $\%$ & $\mathrm{n}$ & $\%$ & $\mathrm{n}$ & $\%$ & $\mathrm{n}$ & $\%$ \\
\hline $\begin{array}{l}\text { excellent } \\
\text { access }\end{array}$ & 39 & $56.5 \%$ & 30 & $60.0 \%$ & 12 & $42.9 \%$ & 38 & $50.7 \%$ & 119 & $55.1 \%$ \\
\hline $\begin{array}{l}\text { very good } \\
\text { access }\end{array}$ & 17 & $24.6 \%$ & 7 & $14.0 \%$ & 9 & $32.1 \%$ & 20 & $26.7 \%$ & 53 & $24.5 \%$ \\
\hline good access & 13 & $18.8 \%$ & 10 & $20.0 \%$ & 3 & $10.7 \%$ & 13 & $17.3 \%$ & 39 & $18.1 \%$ \\
\hline $\begin{array}{l}\text { limited } \\
\text { access }\end{array}$ & 0 & $0.0 \%$ & 2 & $4.0 \%$ & 2 & $7.1 \%$ & 3 & $4.0 \%$ & 7 & $3.2 \%$ \\
\hline $\begin{array}{l}\text { very limited } \\
\text { access }\end{array}$ & 0 & $0.0 \%$ & 0 & $0.0 \%$ & 1 & $3.6 \%$ & 1 & $1.3 \%$ & 2 & $0.9 \%$ \\
\hline none & 0 & $0.0 \%$ & 1 & $2.0 \%$ & 1 & $3.6 \%$ & 0 & $0.0 \%$ & 2 & $0.9 \%$ \\
\hline
\end{tabular}


Lina Miloshevska, Elżbieta Gajek, Nihada Delibegović Džanić \& Çiler Hatipoğlu: Emergency online learning during the first Covid-19 period: students' perspectives

Table 3: Access to the internet

\begin{tabular}{|c|c|c|c|c|c|c|c|c|c|c|}
\hline \multicolumn{11}{|c|}{ Access to the internet } \\
\hline & \multicolumn{2}{|c|}{$\begin{array}{c}\text { BOSNIA AND } \\
\text { HERZEGO- } \\
\text { VINA }\end{array}$} & \multicolumn{2}{|c|}{$\begin{array}{l}\text { NORTH } \\
\text { MACE- } \\
\text { DONIA }\end{array}$} & \multicolumn{2}{|c|}{ POLAND } & \multicolumn{2}{|c|}{ TURKEY } & \multicolumn{2}{|r|}{ All } \\
\hline & $\mathbf{n}$ & $\%$ & $\mathbf{n}$ & $\%$ & $\mathbf{n}$ & $\%$ & $\mathbf{n}$ & $\%$ & $\mathbf{n}$ & $\%$ \\
\hline $\begin{array}{l}\text { excellent } \\
\text { access }\end{array}$ & 25 & $36.2 \%$ & 18 & $36.0 \%$ & 10 & $35.7 \%$ & 24 & $32.0 \%$ & 77 & $35.6 \%$ \\
\hline $\begin{array}{l}\text { very } \\
\text { good } \\
\text { access }\end{array}$ & 20 & $29.0 \%$ & 13 & $26.0 \%$ & 9 & $32.1 \%$ & 20 & $26.7 \%$ & 62 & $28.7 \%$ \\
\hline $\begin{array}{l}\text { good } \\
\text { access }\end{array}$ & 23 & $33.3 \%$ & 16 & $32.0 \%$ & 6 & $21.4 \%$ & 18 & $24.0 \%$ & 63 & $29.2 \%$ \\
\hline $\begin{array}{l}\text { limited } \\
\text { access }\end{array}$ & 3 & $4.3 \%$ & 3 & $6.0 \%$ & 1 & $3.6 \%$ & 10 & $13.3 \%$ & 17 & $7.9 \%$ \\
\hline $\begin{array}{l}\text { very } \\
\text { limited } \\
\text { access }\end{array}$ & 1 & $1.4 \%$ & 0 & $0.0 \%$ & 1 & $3.6 \%$ & 4 & $5.3 \%$ & 6 & $2.8 \%$ \\
\hline none & 0 & $0.0 \%$ & 0 & $0.0 \%$ & 1 & $3.6 \%$ & 0 & $0.0 \%$ & 1 & $0.5 \%$ \\
\hline
\end{tabular}

Table 4 shows the types of devices used by students to follow online instruction. The devices mostly used for online learning are smartphones in Bosnia and Herzegovina N=58 (84.1\%), Turkey N= 59 (78.7\%), Poland N= 13 $(56.5 \%)$, while participants in North Macedonia mostly use desktop computers $\mathrm{N}=39$ (78\%).

Table 4: Devices used by students for online learning

\begin{tabular}{|l|c|c|c|c|c|c|c|c|c|c|}
\hline \multicolumn{8}{|c|}{ Devices for online learning } \\
\hline & $\begin{array}{l}\text { BOSNIA AND } \\
\text { HERZEGOVINA }\end{array}$ & $\begin{array}{c}\text { NORTH } \\
\text { MACEDONIA }\end{array}$ & \multicolumn{2}{|c|}{ POLAND } & \multicolumn{2}{|c|}{ TURKEY } & \multicolumn{2}{|c|}{ All } \\
\hline & $\mathbf{n}$ & $\%$ & $\mathbf{n}$ & $\%$ & $\mathbf{n}$ & $\%$ & $\mathbf{n}$ & $\%$ & $\mathbf{n}$ & $\%$ \\
\hline $\begin{array}{l}\text { Smart } \\
\text { phone }\end{array}$ & 58 & $84.1 \%$ & 28 & $56.0 \%$ & 13 & $56.5 \%$ & 59 & $78.7 \%$ & 158 & $73.1 \%$ \\
\hline $\begin{array}{l}\text { Desktop } \\
\text { computer }\end{array}$ & 56 & $81.2 \%$ & 39 & $78.0 \%$ & 20 & $71.4 \%$ & 54 & $72.0 \%$ & 169 & $78.2 \%$ \\
\hline Laptop & 5 & $7.2 \%$ & 11 & $22.0 \%$ & 0 & $0.0 \%$ & 19 & $25.3 \%$ & 35 & $16.2 \%$ \\
\hline tablet & 4 & $5.8 \%$ & 5 & $10.0 \%$ & 4 & $14.3 \%$ & 10 & $13.3 \%$ & 23 & $10.6 \%$ \\
\hline
\end{tabular}


Besides the excellent/very good access to devices and the internet indicated by most participants in the study, the majority stated that they did not have to share their equipment with family members or roommates: $\mathrm{N}=142$ $(65.7 \%)$. Since the dominant devices used in the online learning period in Bosnia and Herzegovina, Turkey and Poland were smartphones, this might be the reason for the stated high percentages of excellent access to devices and the internet as smartphones are more easily accessible in comparison to desktop computers and laptops. Their performances could be limited, but they could serve the purpose of instant transition to an online learning setting. We may conclude here that our participants had the necessary prerequisites to participate in online classes technically speaking.

In terms of interaction during the online learning period, the data in Table 5 show that students mostly interacted with the teacher whether orally or in a written format (oral interaction with the teacher $\mathrm{N}=199$ (92.1\%); written interaction with the teacher $\mathrm{N}=177(81.9 \%)$, see Table 6$)$

Table 5: Oral interaction patterns in online learning

\begin{tabular}{|c|c|c|c|c|c|c|c|c|c|c|}
\hline \multicolumn{11}{|c|}{ Oral interaction in online learning } \\
\hline & \multicolumn{2}{|c|}{$\begin{array}{c}\text { BOSNIA AND } \\
\text { HERZEGOVI } \\
\text { NA }\end{array}$} & \multicolumn{2}{|c|}{$\begin{array}{l}\text { NORTH } \\
\text { MACE- } \\
\text { DONIA }\end{array}$} & \multicolumn{2}{|c|}{ POLAND } & \multicolumn{2}{|c|}{ TURKEY } & \multicolumn{2}{|c|}{ All } \\
\hline & $\mathrm{n}$ & $\%$ & $\mathrm{n}$ & $\%$ & $\mathrm{n}$ & $\%$ & $\mathrm{n}$ & $\%$ & $\mathrm{n}$ & $\%$ \\
\hline $\begin{array}{l}\text { With } \\
\text { the } \\
\text { teacher }\end{array}$ & 68 & $98.50 \%$ & 46 & $92.0 \%$ & 22 & $95.70 \%$ & 63 & $84 \%$ & 199 & $92.1 \%$ \\
\hline $\begin{array}{l}\text { With a } \\
\text { peer }\end{array}$ & 17 & $24.60 \%$ & 6 & $12.0 \%$ & 5 & $21.70 \%$ & 28 & $37.30 \%$ & 56 & $25.9 \%$ \\
\hline $\begin{array}{l}\text { With a } \\
\text { group } \\
\text { of peers }\end{array}$ & 32 & $46.40 \%$ & 11 & $22.0 \%$ & 12 & $52.20 \%$ & 34 & $45.30 \%$ & 89 & $41.2 \%$ \\
\hline Friends & 0 & $0.0 \%$ & 1 & $2.0 \%$ & 0 & $0.0 \%$ & 0 & $0.0 \%$ & 1 & $0.5 \%$ \\
\hline None & 2 & $2.90 \%$ & 1 & $2.0 \%$ & 0 & $0.0 \%$ & 3 & $4 \%$ & 6 & $2.8 \%$ \\
\hline
\end{tabular}

Although online learning tools offer a variety of possibilities for interaction with peers such as: collaborative work in break rooms, chat, and forums among others it seems that these options have not been fully utilized in our case which resulted in limiting interaction to teacher-student. 
Table 6: Written interaction patterns in online learning

\begin{tabular}{|c|c|c|c|c|c|c|c|c|c|c|}
\hline \multicolumn{11}{|c|}{ Written interaction in Online learning } \\
\hline & \multicolumn{2}{|c|}{$\begin{array}{c}\text { BOSNIA AND } \\
\text { HERZEGO- } \\
\text { VINA }\end{array}$} & \multicolumn{2}{|c|}{$\begin{array}{l}\text { NORTH } \\
\text { MACE- } \\
\text { DONIA }\end{array}$} & \multicolumn{2}{|c|}{ POLAND } & \multicolumn{2}{|c|}{ TURKEY } & \multicolumn{2}{|c|}{ All } \\
\hline & $\mathbf{n}$ & $\%$ & $\mathbf{n}$ & $\%$ & $\mathbf{n}$ & $\%$ & $\mathbf{n}$ & $\%$ & $\mathbf{n}$ & $\%$ \\
\hline $\begin{array}{l}\text { With the } \\
\text { teacher }\end{array}$ & 57 & $82.60 \%$ & 44 & $89.80 \%$ & 16 & $69.60 \%$ & 60 & $80 \%$ & 177 & $81.9 \%$ \\
\hline $\begin{array}{l}\text { With a } \\
\text { peer }\end{array}$ & 30 & $43.50 \%$ & 11 & $22.40 \%$ & 10 & $43.50 \%$ & 49 & $65.30 \%$ & 100 & $46.3 \%$ \\
\hline $\begin{array}{l}\text { With a } \\
\text { group of } \\
\text { peers }\end{array}$ & 25 & $36.20 \%$ & 19 & $38.80 \%$ & 13 & $56.50 \%$ & 42 & $56 \%$ & 99 & $45.8 \%$ \\
\hline $\begin{array}{l}\text { With the } \\
\text { course } \\
\text { assistant }\end{array}$ & 0 & $0.0 \%$ & 0 & $0.0 \%$ & 0 & $0.0 \%$ & 3 & $4 \%$ & 3 & $1.4 \%$ \\
\hline $\begin{array}{l}\text { with } \\
\text { Google }\end{array}$ & 1 & $0.0 \%$ & 0 & $0.0 \%$ & 0 & $0.0 \%$ & 1 & $1.30 \%$ & 2 & $0.9 \%$ \\
\hline None & 0 & 0 & 1 & $2 \%$ & 0 & $0.0 \%$ & 1 & $1.30 \%$ & 2 & $0.9 \%$ \\
\hline
\end{tabular}

Such limited interaction might have an impact not only on learning achievements of students but also on their general wellbeing. Educators and psychologists are rightly concerned about the psycho-social consequences for individuals who are confined at home with limited interaction with others. For students, the loss of contact with peers and teachers, constitute serious threats to their physical and mental health. For teachers, also the challenges have not only been pedagogical but also personal, psychological, professional and emotional. All of which have been more intense and difficult to manage (Stanistreet et al., 2021: 628).

The data show that the abrupt shift to online instruction did not considerably affect the manner through which students complete course requirements as most participants $\mathrm{N}=181(83.8 \%)$ stated that during the online learning period they had read the uploaded materials and submitted their assignments. Figure 2 below illustrates the data in terms of learning practices by students. 


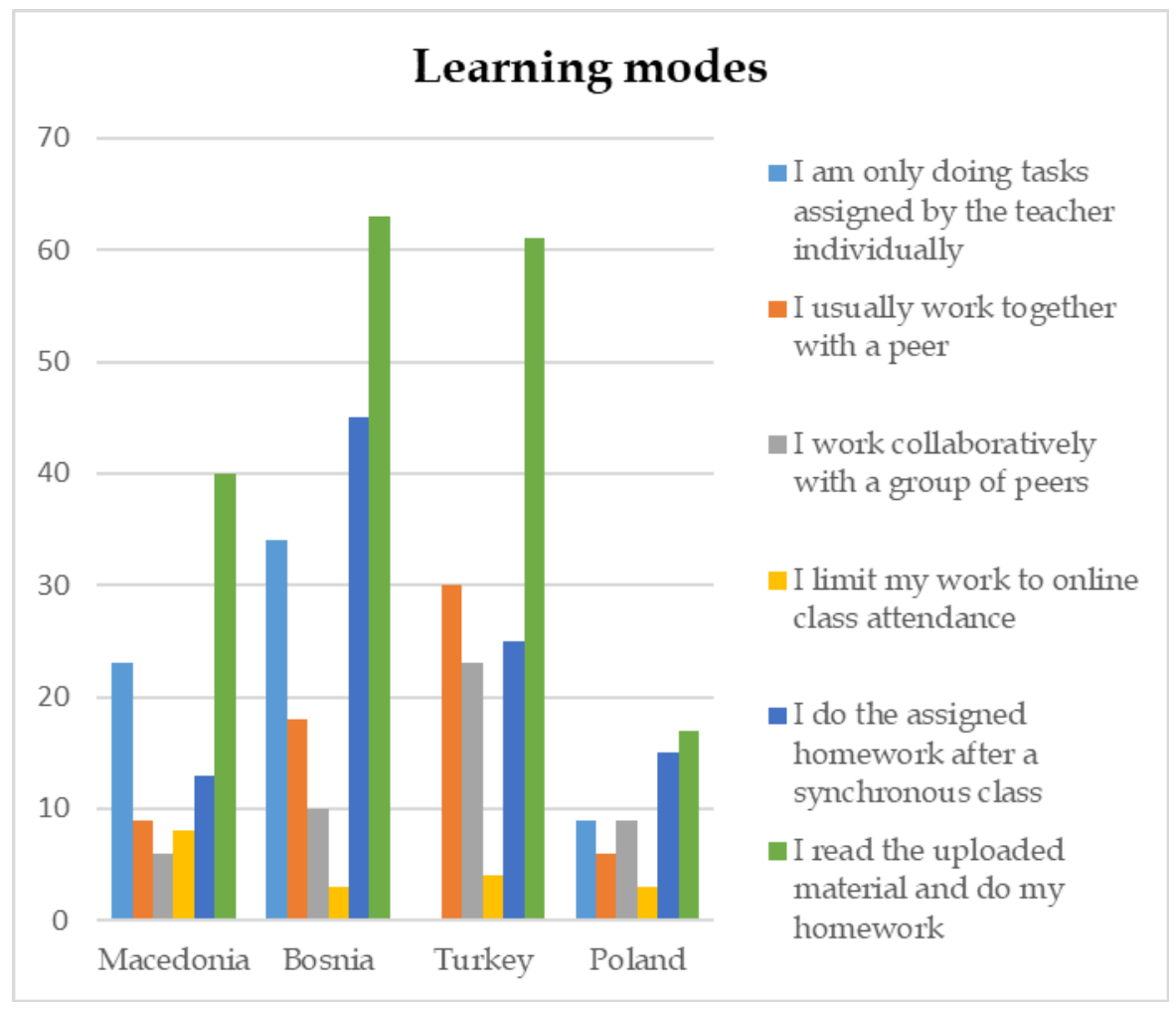

Figure 2: Learning practices of students during online learning

The reasons behind this classic practice and lack of collaboration might be due to two reasons discussed in Rapanta et al. (2020). Teachers either followed a materials-based approach: teachers share materials with learners and expect them to produce materials, or a tools-based approach to online teaching which is based on the idea that tools such as videoconferencing or text-based discussion boards are the key features of online learning. Of course neither approaches are sufficient for a fruitful online learning experience without complete awareness of "pedagogical content design" that involves instructional design, and learning design adapted to a particular context (ibid).

We asked students to indicate the sources of support provided to them during the online learning period. Data in Table 7 show that most participants $\mathrm{N}=149(69 \%)$ stated the teacher as the first support provider and $\mathrm{N}=93$ $(43.1 \%)$ stated peers as the second source of support. However, in North Macedonia $\mathrm{N}=33(67.3 \%)$ stated family members as the primary source of support during the online learning period with the teacher taking second place $\mathrm{N}=29$ (59.2\%). 
Table 7: Support providers during online learning

\begin{tabular}{|c|c|c|c|c|c|c|c|c|c|c|}
\hline \multicolumn{11}{|c|}{ Support providers during online learning } \\
\hline & \multicolumn{2}{|c|}{$\begin{array}{c}\text { Bosnia \& } \\
\text { Herzegovin } \\
\text { a }\end{array}$} & \multicolumn{2}{|c|}{$\begin{array}{c}\text { North } \\
\text { Macedonia }\end{array}$} & \multicolumn{2}{|c|}{ Turkey } & \multicolumn{2}{|c|}{ Poland } & \multicolumn{2}{|c|}{ All } \\
\hline & $\mathbf{N}$ & $\%$ & $\mathbf{N}$ & $\%$ & $\mathbf{N}$ & $\%$ & $\mathbf{N}$ & $\%$ & $\mathbf{N}$ & $\%$ \\
\hline $\begin{array}{l}\text { The } \\
\text { teacher/The } \\
\text { course } \\
\text { instructor }\end{array}$ & 49 & $71.0 \%$ & 29 & $59.2 \%$ & 54 & $72.0 \%$ & 17 & $73.9 \%$ & 149 & $69.0 \%$ \\
\hline $\begin{array}{l}\text { The course } \\
\text { assistant }\end{array}$ & & & & & 30 & $40.0 \%$ & & & 30 & $13.9 \%$ \\
\hline $\begin{array}{l}\text { My } \\
\text { colleagues }\end{array}$ & 41 & $59.4 \%$ & 23 & $46.9 \%$ & 12 & $16.0 \%$ & 8 & $34.8 \%$ & 84 & $38.9 \%$ \\
\hline My peers & 24 & $34.8 \%$ & 11 & $22.4 \%$ & 46 & $61.3 \%$ & 12 & $52.2 \%$ & 93 & $43.1 \%$ \\
\hline $\begin{array}{l}\text { Family } \\
\text { members }\end{array}$ & 39 & $56.5 \%$ & 33 & $67.3 \%$ & 33 & $44.0 \%$ & 12 & $52.2 \%$ & 117 & $54.2 \%$ \\
\hline Online tutor & & $1.4 \%$ & 1 & $2.0 \%$ & & & & & 1 & $0.5 \%$ \\
\hline Myself & 1 & & & & 7 & $9.3 \%$ & & & 8 & $3.7 \%$ \\
\hline No one & & & & & 4 & $5.3 \%$ & & & 4 & $1.9 \%$ \\
\hline None & & & 1 & $2.0 \%$ & & & & & 1 & $0.5 \%$ \\
\hline
\end{tabular}

The emergency online education experience had its advantages and challenges. As the move to online instruction literally happened overnight, not all educational institutions had the necessary technology nor expertise for a successful implementation of online instruction. On the other hand, not all students had the necessary conditions to follow online classes. Some of the most commonly mentioned difficulties encountered by students were: technical difficulties e.g. unstable internet connection, limited access to the internet, limited access to devices, lack of motivation, lack of concentration due to boring instruction, confusion due to lack of organization on the students' side, confusion due to lack of organization and clear guidelines from the educational institution, being overwhelmed due to the large number of online classes and activities with sometimes overlapping schedules, lack of support and guidance from the educational authorities. The data are given in Figure 3 below. 


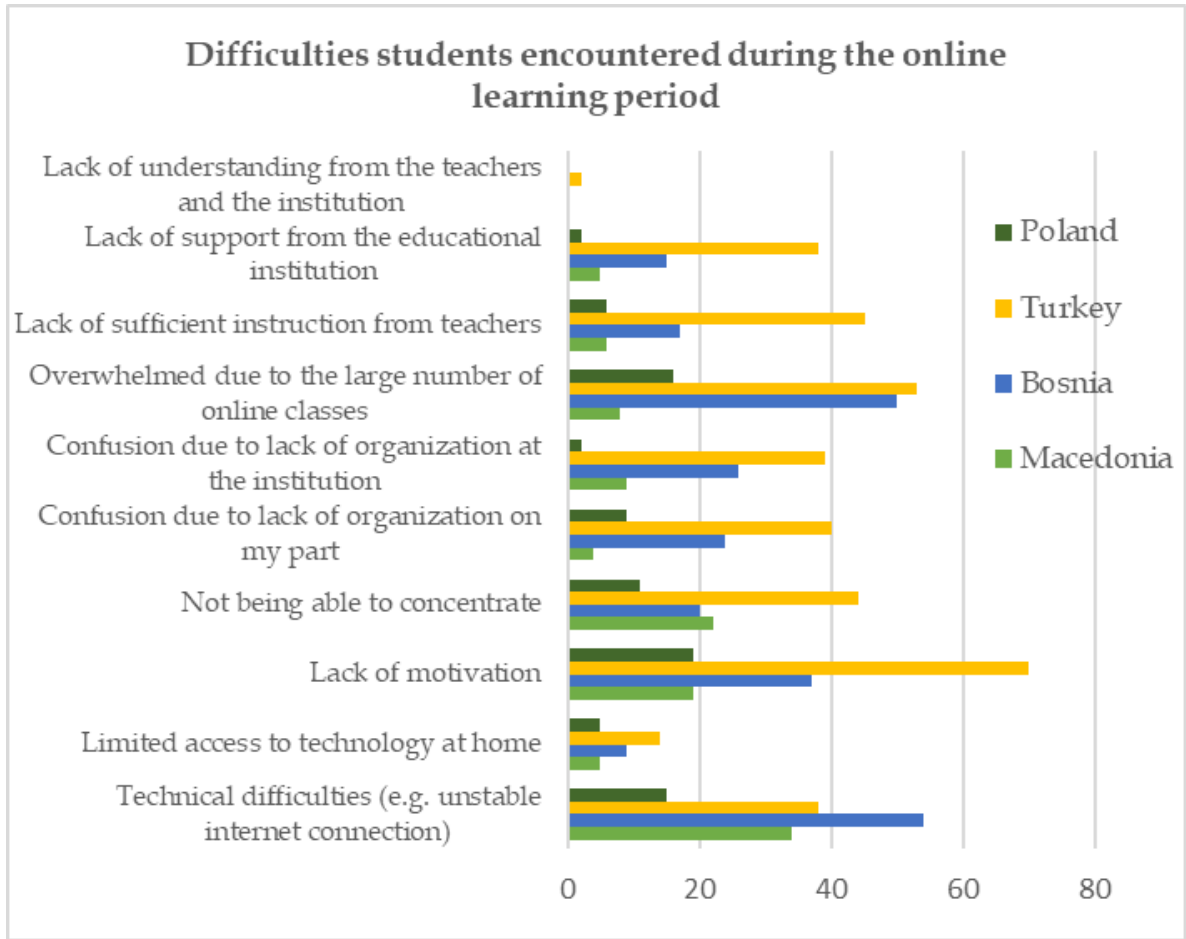

Figure 3: Difficulties students encountered during the emergency online learning

As displayed in Figure 3 above, 'Lack of motivation' is the most common difficulty faced by students N=145 (67.1\%). Technical difficulties (poor or unstable internet connection) is stated by 141 respondents $65,3 \%$. At first glance, this finding might appear to contradict the data discussed in Table 2 and Table 3 above where students in the present study mostly indicated that they had excellent or very good access to the internet, yet on second thought students might be right in stating unstable internet as a very common issue they faced. As curfews and lockdowns were imposed in the period between March-June 2020 and people spent more time at home and consequently more time online, online traffic skyrocketed to unprecedented levels which led to overwhelming the network.

Section 3 of the survey aimed at capturing students' attitudes in relation to their online learning experience. Having experienced online learning for most of the spring semester of 2020 (March-June 2020), students were asked to rate their online learning experience in terms of its efficiency, usefulness, ease, accessibility, its positive or negative implications for the learning process, and the used online learning tools. 
Question 18 of the survey asked participants to rate their online learning experience in relation to the following statements:

- Online learning facilitates the fulfilment of course requirements

- Online learning is effective

- Online learning increases the quality of teaching

- Online learning is motivating

- Online learning speeds up the learning process

As to whether online learning facilitates the fulfilment of course requirements, $\mathrm{N}=99(45.8 \%)$ in all four countries believe it does. However, $\mathrm{N}=95$ $(44 \%)$ are neutral. Just over one-third of students $N=81$ (37.5\%) agree that online learning is effective. However, $\mathrm{N}=75$ (34.7\%) believe the opposite. Looking at country specific data, it is worth mentioning that almost half of Turkish students $\mathrm{N}=38$ (50.7\%) do not think that online learning is effective. By contrast, about half of Macedonian students $\mathrm{N}=26$ (53.1\%) believe that online learning is effective. The students from Bosnia and Herzegovina and Poland are mostly undecided in this regard. Most students in all four countries do not think that online instruction increases the quality of teaching, $\mathrm{N}=121(56 \%)$ with the highest disagreement appearing in Turkey $\mathrm{N}=59$ $(78.7 \%)$. Most students do not agree that online learning is motivating, $\mathrm{N}=138(63.9 \%)$. Again, the highest percentage of disagreement comes from Turkey, $\mathrm{N}=63(84 \%)$. The data here confirm the data reported in figure 3, where Polish and Turkish students overwhelmingly stated lack of motivation as the number one challenge they faced during online learning. As to whether online learning speeds up the learning process, $\mathrm{N}=98$ (45.4\%) think it does. However, $\mathrm{N}=42(56 \%)$ of Turkish students have the opposite opinion.

Question 19 of the survey asked students to rate online learning tools used during the emergency online learning period in terms of their ease of use, practicality, convenience, accessibility of instruction, and mental effort required for their use. Students in all countries positively rated online learning tools in relation to the above aspects. Namely, the majority of students $\mathrm{N}=175(81 \%)$ think that online learning tools are easy to use. Also, N=135 $(62.5 \%)$ of the students think that online learning tools do not require a lot of mental effort. Most students in all four countries N=186 (86.1\%) believe that online learning tools are practical, instructions are easily accessible $\mathrm{N}=150$ $(69.4 \%)$, and are convenient $\mathrm{N}=132(61.1 \%)$. Since most students in the survey stated that their computer literacy is advanced, it seems that they had no difficulty using these tools and hence the positive attitude towards the tools.

Q20 of the survey explores attitudes toward online learning and attempts to get students' evaluation of their online learning experience in relation to the following statements: 
- I like online learning

- Online learning provides an attractive learning environment

- Online learning is useless

- My experiences with online learning are positive

- I think that most of the courses in higher education should be taught online

- I am against online learning

- Online learning is better than traditional learning

- I think I will get better grades because of online learning

- I find that I can learn more through online learning than through traditional learning

Overall, 95 students (44\%) in all four countries stated that they dislike online learning. Students in Bosnia and Herzegovina and Turkey expressed the highest percentage of dislike of online learning with 32 respondents $46.4 \%$ in Bosnia and Herzegovina and 42 respondents 56\% in Turkey. Macedonian and Polish students are slightly more in favor of online learning: MK $\mathrm{N}=20(40.8 \%), \mathrm{PL} \mathrm{N}=9$ (39.1\%). Whether online learning provides an attractive learning environment, $\mathrm{N}=97(44.9 \%)$ of students think that online learning does not provide an attractive learning environment. The highest numbers opposing the statement are among students from Turkey $\mathrm{N}=49(65.3 \%)$. In spite of this, almost half of the students, $\mathrm{N}=106$ (49.1\%), in all countries do not think that online learning is useless.

In terms of their overall experience with online learning, students in Bosnia and Herzegovina are mostly neutral $\mathrm{N}=28(40.6 \%)$. Students in Turkey rated their overall experience with online learning as mostly negative $\mathrm{N}=42$ (56\%). Students in North Macedonia N=27 (55.1\%), and students in Poland $\mathrm{N}=11(47.8 \%)$ stated that their experience with online learning is positive.

Nevertheless, and in spite of positively evaluating online learning tools for their ease of use and convenience, as reported above, most students, $\mathrm{N}=132(61.1 \%)$, do not believe that online learning is better than in-person learning. In addition, $\mathrm{N}=101$ (46.8\%) of students do not think that they will get better grades because of online learning, nor that they can learn more through online learning, $\mathrm{N}=128$ (59.3\%). We might conclude that students are not against online learning per se; they recognize and appreciate the convenience that online learning tools offer, yet they do not think that it should replace face-to-face learning. Another important conclusion that emerges from the data is that Turkish and Bosnian students express a predominantly negative view towards online learning compared to Macedonian and Polish students who are mostly positive or neutral.

Section 4 of the survey is focused on the effects of online learning on students as to whether online learning changed the way students study and prepare for exams, which aspects of online learning should be integrated in 
the educational offer beyond the pandemic and what aspects of in-person learning students miss. The majority of Turkish students $\mathrm{N}=50(66.7 \%)$ and Polish students $\mathrm{N}=16(69.6 \%)$ stated that online learning changed the way they learn. While most Macedonian students $\mathrm{N}=30$ (61.2\%) and Bosnian students $\mathrm{N}=40(58 \%)$ stated that online learning has not affected the way they learn. Probably the reasons behind are due to the teaching methods in North Macedonia and Bosnia and Herzegovina and are related to findings discussed under Figure 2. To teach online is far more complex than to connect to Zoom and stream/share the screen with students. It requires different course design, preparation, approach and interaction. Such preparation it seems, has been missing in North Macedonia and Bosnia and Herzegovina in the period covered by this study as institutions and teachers had no time to redesign and adapt their courses for the online environment.

In relation to future implications of online learning i.e. if online learning should remain and be part of most courses in higher education, our respondents mostly disagree with this idea: $\mathrm{N}=124(57.4 \%)$. However, students believe that certain aspects of online learning should be part of the educational offer after the pandemic is over, Figure 4 displays the findings.

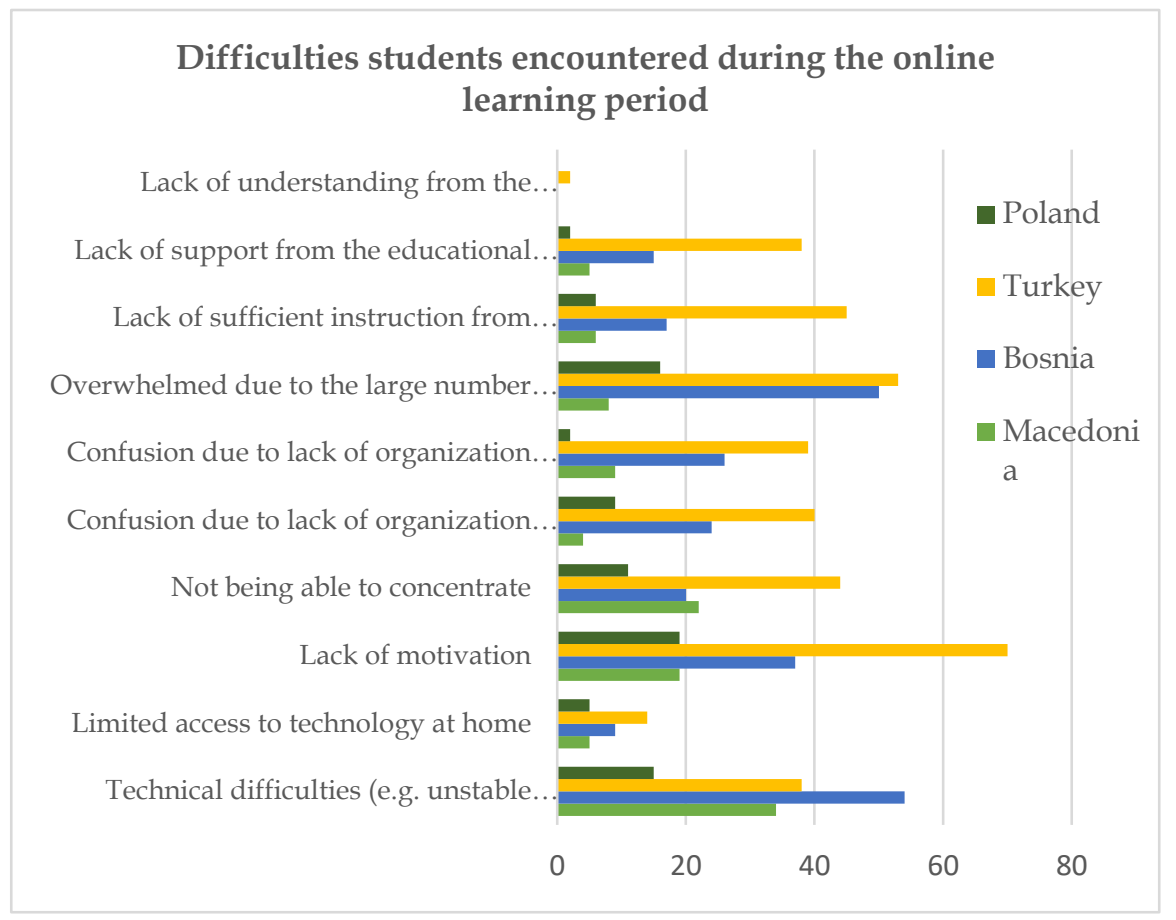

Figure 4: Element of online learning that should remain beyond the pandemic 
As Figure 4 shows, most students, N=154 (71.3\%), would like digital distribution of class materials to remain. In addition, $\mathrm{N}=140(64.8 \%)$ think that online consultations with the teacher should be part of the educational offer beyond the pandemic. Moreover, $\mathrm{N}=125$ (57.9\%) of students think that online participation in classes for sick or disabled students should be offered at higher education institutions. It remains to be seen to what extent higher education institutions will integrate these features in their constant instructional offerings when the pandemic is over and students and teachers go back to their campuses. However, according to an Ipsos survey for the World Economic Forum, higher education in 2025 will be a hybrid of inperson and online learning. ${ }^{21}$

Figure 5 shows which aspects of in-person teaching students missed the most during the emergency online learning period.

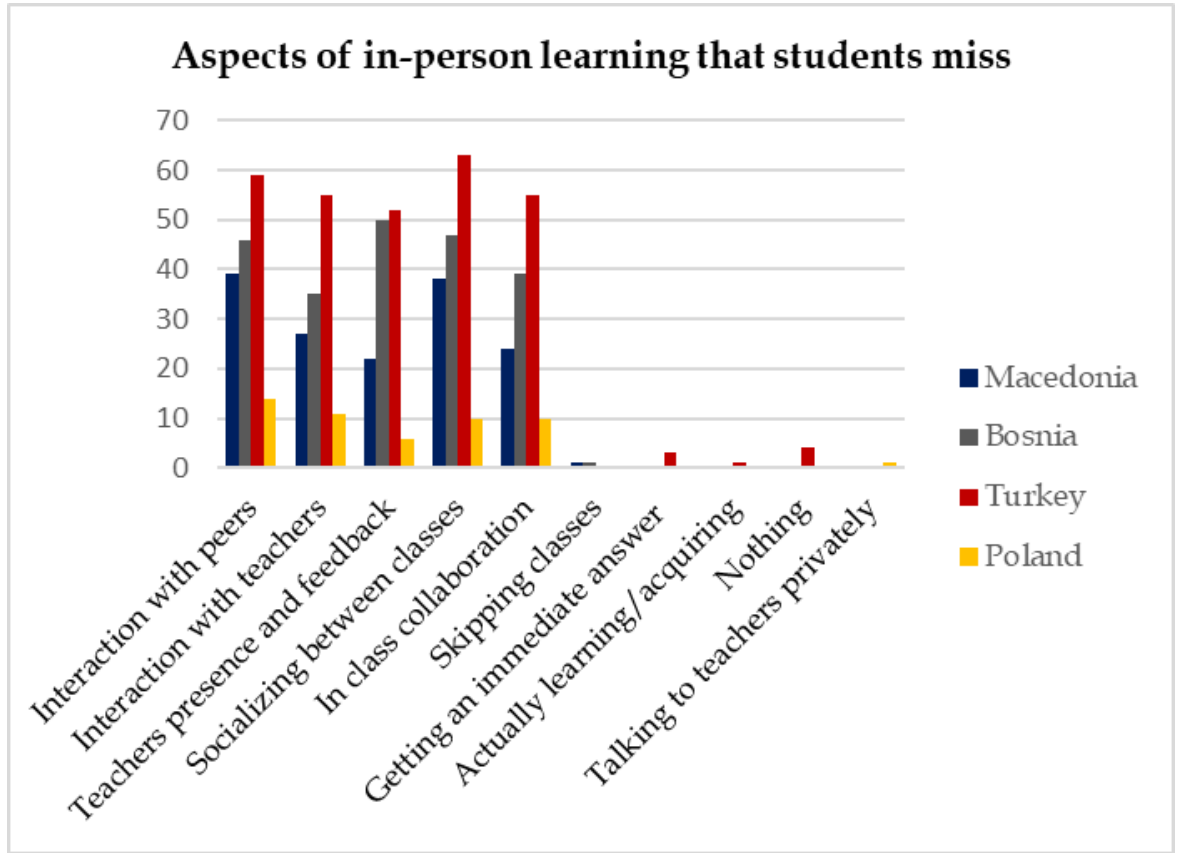

Figure 5: Aspects of in-person learning that students miss

Figure 5 shows that $\mathrm{N}=158(73.1 \%)$ miss interaction with peers and an equal number stated that they miss socializing between classes. The issue of lack of interaction in online learning has been pointed to in Table 5 and 6 above. Students also miss interaction with teachers $\mathrm{N}=128$ (59.3\%) and

\footnotetext{
${ }^{21}$ https://www.ipsos.com/en-ru/global-views-person-vs-online-education
} 
equally miss in-class collaboration. A significant number of students $N=130$ $(60.2 \%)$ stated that they miss the teachers' presence and feedback. Of course, all of these aspects i.e. interaction with peers, socializing, interaction with teachers and teachers' presence are part of the complex and rich educational experience that an individual engages with by being part of an academic community. Many of these aspects during the first emergency online learning period according to our respondents were missing. It seems that although online learning might provide an efficient delivery of instruction and satisfactory learning outcomes it could not fully replace the meaningful, and complex experience that in-campus interaction offers on matters that are not only restricted to learning but to growing up and maturing while being part of a rich academic setting.

\section{Conclusions}

Covid-19 pandemic disrupted traditional teaching methods around the globe. The educational institutions in North Macedonia, Bosnia and Herzegovina, Poland and Turkey moved to remote instruction abruptly without being fully prepared. The novelty of remote instruction focused on delivering online instruction using videoconferencing tools. Other tools of remote instruction such as learning management systems have already been in use in the four countries of the study, and hence both teachers and students had no difficulty in continuing to use them.

Although the four countries of the study have different educational systems, all responded in a similar way to the pandemic and applied similar measures. The results show more similarities than differences in terms of students' attitude towards online learning. The students demonstrated that they have acquired most of the competences needed for online learning in terms of effective use of digital tools for online learning. However, they are far from feeling comfortable in the new environment particularly in terms of social and affective aspects of learning. Lack of interaction with peers seems to be an issue in online learning, as most participants in the study indicated. It is also important to highlight that due to imposed restrictions a lot of students were not able to meet their peers in their free time, which further contributed to their social anxiety. Unstable internet connection is the most common difficulty that participants in the study faced during the Covid-19 remote instruction period. Although most participants in the study stated that they have excellent or very good access to the internet yet problems with internet connection might be due to the overwhelmed network since many businesses moved to working online and both students and parents had to stay at home for extended periods of time which forced people to spend more time online. 
Lack of motivation is an issue that most students in our study faced during the Covid-19 online learning period. Our findings contradict the findings in (Agarwal \& Kaushik, 2020) that argue that online learning had a positive impact on the morale of students by creating a distraction from the ongoing pandemic. Motivation is a topic that has been studied substantially by educators, pedagogues, and philosophers. Based on the findings of the current study, we recommend that educational institutions make the effort to increase students' motivation in online classes by redesigning curricula to be fit for online instruction. Instruction should be interesting, interactive, engaging, mindful of circumstances, has varied activities, frequent short breaks, meaningful support and feedback and most importantly clear communication of objectives, expectations, and responsibilities. After going through online learning for a year now (the time of writing this paper), and given the high uncertainty as to vaccination, it seems that the initial objective of providing a continuity of the educational process through technology has been achieved in the countries of the study and the focus now and for the future should be on online pedagogy.

Turkish and Bosnian participants expressed the most negative attitude towards online learning. They believe that online learning is not motivating, it does not increase the quality of instruction and it is not effective. However, online learning tools used during the Covid-19 crisis were positively rated by all participants in the four countries in terms of their ease of use, practicality, accessibility and convenience. This leads to the conclusion that students are not against online learning per se as they appear to appreciate the opportunities it brings to the educational offer, yet they would not replace in-person learning with online learning. Students suggested online learning should remain as part of the educational possibilities when physical presence is not possible.

\section{References}

Agarwal, Sakshi, Jaya Shankar Kaushik (2020). Student's perception of online learning during COVID pandemic. The Indian Journal of Pediatrics 87: 554-554. https:/ / doi.org/10.1007/s12098-020-03327-7

Alkan, Cevat (1987). Açıköğretim: Uzaktan Ĕ̆itim Sistemlerinin Karşılaştırmalı Olarak İncelenmesi. Ankara: Ankara Üniversitesi Eğitim Bilimleri Fakültesi Yayınlar1 157.

Bonal, Xavier, Sheila González (2020). The impact of lockdown on the learning gap: family and school divisions in times of crisis. International Review of Education 66: 635-655.

Botkin, James W., Mahdi Elmandjra, Mircea Malitza (1979). No Limits to Learning: Bridging the Human Gap. A Report to the Club of Rome. Pergamon Press. 
Chapelle, Carol (1990). The discourse of computer-assisted language learning: Toward a context for descriptive research. TESOL Quarterly 24(2): 199-225.

Chapelle, Carol (1995). A framework for the investigation of CALL as a context for SLA. CAELL Journal 6(3): 2-8.

Chapelle, Carol, Joan Jamieson (1986). Computer-assisted language learning as a predictor of success in acquiring English as a second language. TESOL Quarterly 20(1): 27-46.

Chapelle, Carol, Joan Jamieson (1989). Research trends in computer-assisted language learning. Pennington, Martha C., ed. Teaching languages with computers: The state of the art. La Jolla: Athelstan, 47-59.

Comenius, J.A. (1657) Didactica Magna.

Crawford, Joseph, Kerryn Butler-Henderson, Jürgen Rudolph, Bashar Malkawi, Matt Glowatz, Rob Burton, Paulo Magni, Sophia Lam (2020). COVID-19: 20 countries' higher education intra-period digital pedagogy responses. Journal of Applied Learning \& Teaching 3 (1): 1-20.

http://journals.sfu.ca/jalt/index.php/jalt /index

Cresson, Edith (1995). White Paper: Teaching and Learning: Towards the Learning Society. Brussels: Commission of the European Communities.

Delors, Jacques (1996). Learning: The Treasure within: Report to UNESCO of the International Commission on Education for the Twenty-first Century. UNESCO Publishing, Paris.

Elfert, Maren (2019). Revisiting the Faure Report and the Delors Report: Why was UNESCO's utopian vision of lifelong learning an "unfailure"? Finnegan, Fergal and Bernie Grummell, eds. Power and Possibility. Adult Education in a Diverse and Complex World. Leiden: Brill Sense, 17-25.

Faure, Edgar (1973). Learning to Be: The World of Education Today and Tomorrow. Paris: UNESCO.

Geray, Cevat. (2007). Distance education in Turkey. International Journal of Educational Policies 1(1): 33-62.

Guerriero, Sonia. ed. (2017). Pedagogical Knowledge and the Changing Nature of the Teaching Profession. Paris: OECD Publishing. http:/ /dx.doi.org/10.1787/9789264270695-en

Healey, Deborah, Elizabeth Hanson-Smith, Philip Hubbard, Sophie IoannouGeorgiou, Greg Kessler, Paige Ware (2011). TESOL Technology Standards: Description, Implementation, Integration. Alexandria, VA: TESOL.

Hatipoğlu, Çiler (2010). Summative evaluation of an English language testing and evaluation course for future English language teachers in Turkey. English Language Teacher Education and Development (ELTED) 13: 40-51.

Hatipoğlu, Çiler (2016). The impact of the university entrance exam on EFL education in Turkey: Pre-service English language teachers' perspective. ProcediaSocial and Behavioral Sciences 232: 136-144.

Hatipoğlu, Çiler (2017). History of English language teacher training and English language testing and evaluation (ELTE) education in Turkey. Bayyurt, Yasemin and Nicos Sifakis, eds. English Language Education Policies and Practices in the Mediterranean Countries and Beyond. Frankfurt: Peter Lang, 227-257.

Hatipoğlu, Çiler, Elżbieta Gajek, Lina Miloshevska, Nihada Delibegović Džanić. (2020). Crowdsourcing for widening participation and learning opportunities: a view from language learners' window. Frederiksen, Karen-Margrete, Sanne 
Larsen, Linda Bradley and Sylvie Thousnëy, eds. CALL for Widening Participation: Short Papers from EUROCALL 2020. Research-publishing.net, 81-87. https://doi.org/10.14705/rpnet.2020.48.1169

Hauck, Mirjam (2005). Metacognitive knowledge, metacognitive strategies, and CALL. Egbert, Joy L., Petrie, G. eds. CALL Research Perspectives. New Jersey, USA:Lawrence Erlbaum, 65-86.

Hauck, Mirjam, Stella Hurd (2005). Exploring the link between language anxiety and learner self-management in open language learning contexts. European Journal of Open, Distance and E-learning 8(2).

Jena, Pravat Kumar (2020). Impact of pandemic COVID-19 on education in India. International Journal of Current Research (IJCR) 12: 12582-12586.

http://journalcra.com/article/impact-pandemic-covid-19-education-india,

Karayalçın, Yaşar (1959). Mektupla Ögretim (Educating with Letters). Ankara Üniversitesi Hukuk Fakültesi [Ankara University Faculty of Law Publications].

Memic Fišić, Nihada Delibegović Džanić (2020). A comparative study of Bosnian and Herzegovinian adult foreign language students' attitudes to teaching four skills in classroom and distance language learning systems. ELT Research Journal 9(1): 9-27.

OECD (2018). A Teachers Guide to TALIS 2018. https://www.oecd.org/education /talis/TALIS-Teachers-Guide-to-TALIS-2018-Vol-I_ENG.pdf.

Paniagua, Alejandro, David Istance (2018). Teachers as Designers of Learning Environments: The Importance of Innovative Pedagogies. Educational Research and Innovation. Paris: OECD Publishing.

Rapanta, Chrysi, Luca Botturi, Peter Goodyear, Lourdes Guàrdia, Marguerite Koole (2020). Online university teaching during and after the Covid-19 crisis: Refocusing teacher presence and learning activity. Postdigital Science and Education 2: 923-945. https:/ / doi.org/10.1007/s42438-020-00155-y

Reimers, Fernando M., Andreas Schleicher (2020). A framework to guide an education response to the COVID-19 Pandemic of 2020. Paris: OECD.

Şimşek, Hasan (1999). The Turkish higher education system in the 1990s. Mediterranean Journal of Educational Studies 4 (2): 133-153.

Stanistreet, Paul, Maren Elfert, David Atchoarena (2021). Education in the age of COVID-19: Understanding the consequences. International Review of Education 66: 627-633.

UNICEF (2020). COVID-19: Are children able to continue learning during school closures? A global analysis of the potential reach of remote learning policies. https:/ / data.unicef.org/resources/remote-learning-reachability-factsheet/

\section{Authors' addresses:}

\section{Lina Miloshevska}

University of Information Science and Technology "St. Paul the Apostle"Ohrid, Republic of North Macedonia.

email: lina.milos@gmail.com.

https://orcid.org/0000-0003-3856-5448 
Elżbieta Gajek:

University of Warsaw - Warsaw, Poland.

email e.gajek@uw.edu.pl.

https:/ / orcid.org/0000-0003-2971-8334

Nihada Delibegović Džanić

Faculty of Humanities and Social Sciences

University of Tuzla

Dr. Tihomila Markovića 1

75000 Tuzla

email: nihada.delibegovic@unitz.ba

Çiler Hatipoğlu

Middle East Technical University,

Ankara, Turkey

email: cier@metu.edu.tr

https://orcid.org/0000-0002-7171-1673

Received: March 10, 2021

Accepted for publication: April 7, 2021 